\title{
A Comparative Study on Marketing Mix Models for Digital Products *
}

\author{
KanLiang Wang ${ }^{1}$ Yuan Wang ${ }^{1}$ JingTao Yao ${ }^{2}$ \\ 1 School of Management, Xi'an Jiaotong University, P.R. China \\ 2 Department of Computer Science, University of Regina, Canada \\ klwang@mail.xjtu.edu.cn, wy0179wang@163.com, jtyao@cs.uregina.ca
}

\begin{abstract}
The rise of the Internet and electronic commerce provide a huge marketspace and unique transaction process for digital products. It is significant to discuss whether established marketing models can be revised for digital products. First, the unique features of digital products are systematically reviewed, and then three typical digital products, including e-books, anti-virus, and online translation services, are analyzed and compared utilizing three established marketing models, including $4 \mathrm{P}, 4 \mathrm{C}$, and $4 \mathrm{~S}$. We find that these marketing mix models have different suitability for three typical digital products. The intention of this paper is to provide a reference for enterprises in selecting marketing mix model according to product's categories and to provide a marketing strategy tool kit.
\end{abstract}

\section{Introduction}

The integration of technology will lead to an overall shift in the behavior and competition strategy of market participants [1]. It is interesting to discuss whether established marketing models can serve for digital products while great changes happen in market environment and in product's characteristics. By nature, digital products can be transacted and delivered through the Internet [2]. Information, payment, and delivery related with digital product's transaction are integrated into the Internet channel. For the transactions of physical products, it must be accompanied by off-line or physical logistics [3].

With unique characteristics in economic and physical property, digital products have many differences from physical products in marketing strategy. For example, all digital products can be transacted without the need for a medium to carry them, since the cost of distribution and production is near zero. The problem is that margin-cost pricing is not available. So the suitability of $4 \mathrm{P}$ (product, price, place, promotion) marketing model in an E-environment has been questioned [4]. Mahajan and Venkatesh [5] share the same opinion, opportunity and challenge are brought to E-Business with the rapid development of the Internet, still existing models may have objective conflicts, long-term profit

\footnotetext{
* This research is supported by NSF of China under Grants 70372049 and ChunHui Project from Ministry of Education of China.
} 
maximization is appropriate for E-Business firms as well, yet, increasing customer share and realizing profits and/or cash flow may be important in the short term, so existing models may not fit well in E-Business situations.

About the validity of $4 \mathrm{P}$ marketing mix model in digital space, a typical argument is "...marketers should focus on playing an active role in the construction of new organic paradigms for facilitating commerce in the emerging electronic society underlying the web, rather than infiltrating the existing primitive mechanical structures... [6]". Following this issue, many new models are put forward to replace the $4 \mathrm{P}$ model in digital marketspace[2][7][8][9][10][11][12][13], such as $4 \mathrm{C}, 4 \mathrm{~S}, 5 \mathrm{P}, 7 \mathrm{P}$, ICDT and three "flow" models. Among these alternatives, the $4 \mathrm{C}$ and $4 \mathrm{~S}$ model have wildspread influence. According to Lauterbor, the $4 \mathrm{P}$ model can not fit well in E-market, which should be replaced by the $4 \mathrm{C}$ model (consumer wants and needs, cost to satisfy, convenience to buy, and communication)[7]. The $4 \mathrm{~S}$ web marketing model (scope, site, synergy and system) is put forward by Constantinides [10], which is designed for depicting enterprise strategy in E-Business.

Therefore, the 4P marketing mix model may not valid on the Internet age, the $4 \mathrm{C}$ and the $4 \mathrm{~S}$ model are some alternatives. The intention of this research is to study the suitability of those three marketing mix models for digital products in digital space. It is hoped to find which marketing mix model fit well for different types of digital products. Therefore, a tool kit of marketing strategies is developed for professionals selling digital products.

\section{Characteristics and Categories of Digital Products}

Different marketing strategies may be applied to different types of digital products due to their unique characteristics [14]. It is very important to sum up the characteristics of digital products for investigating the suitability of the established marketing mix model. Most digital products share the following economic characteristics.

Production The production of digital products is always associated with a huge fixed cost and negligible margin cost [15].

Public goods Digital products have some consumption characteristics of public goods, such as non-exclusiveness and non-rivalry [16].

Network externality Contrary to the basic principle of traditional economics, digital products with positive feedback abide by the principle of "more abundant, more precious" [17].

It is possible that non-digital products share some characteristics above. But digital products also possess some unique physical characteristics at the same time.

Attrition-free Once produced, they will exist forever with the same quality. Furthermore, the competition must spread between new digital products and second-hand digital products. 
Changeability The content of digital products can be changed or customized easily [18]. The integrity can not be controlled by manufacturer after downloaded by users.

Replication It is most meritorious that digital products can be shared, replicated, stocked and transferred easily. After the first copy of a digital product is created, it can be manufactured with a very low marginal cost. Digital products are composed of text, graph, and voice etc. They are heterogeneous because all the components can be reconstructed quickly and easily. Therefore, it is important to classify various digital products.

In this paper, we adopt the framework put forward by Hui \& Chau [19] which classified digital products into three categories according to three dimensions including trialability, granularity and downloadability (Fig. 1). Those are utilities and tools, content-based digital products and online services.

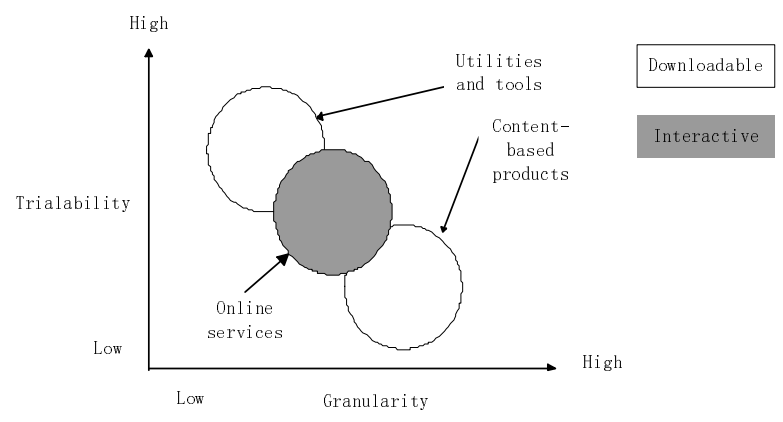

Fig. 1. classifying digital products [19]

These three categories of digital products exhibit differences in trialability, granularity and downloadability(See Table 1). We argue that different categories of digital products require different marketing mix models .

Table 1. Characteristic comparison of different categories of digital products [19]

\begin{tabular}{l|l|l|l|l}
\hline Category & Trialability & Delivery mode & Granularity & Example \\
\hline $\begin{array}{l}\text { Content-based digi- } \\
\text { tal products }\end{array}$ & Low & By download & High & e-book \\
\hline Utilities and tools & High & By download & Low & Anti-virus software \\
\hline Online services & Medium & Interactive & Medium & Online translation \\
\hline
\end{tabular}

\section{Marketing Strategy Analysis of Different Digital Products}

The classic $4 \mathrm{P}$ marketing model, the $4 \mathrm{C}$ marketing model and the $4 \mathrm{~S}$ marketing model are summarized from different business backgrounds. Constantinides suggest that the background of $4 \mathrm{P}$ is industrialization which is characterized 
by enterprise-centric[10]. With the shift of power from enterprise to consumer, the $4 \mathrm{C}$ model is put forward, which is characterized by customer-centric. The $4 \mathrm{~S}$ marketing model was created for E-Business environment [10]. For different business backgrounds of three marketing mix models, We argue that the $4 \mathrm{P}$, $4 \mathrm{C}$ and $4 \mathrm{~S}$ marketing mix models have different suitability for three categories digital products.

In this section, we will analyze the suitability of three models for three different categories of digital products.

\subsection{P Marketing Mix}

The $4 \mathrm{P}$ model delimit four distinct, well-defined and independent management processes. Despite the consistent effort by many physical businesses to deal with the $4 \mathrm{P}$ in an integrated manner, the drafting but mainly the implementation of the $\mathrm{P}$ policies remains largely the task of various departments and persons within the organization. Even more significant thought is the fact that the customer is typically experiencing the individual effects of each of the 4Ps in diverse occasions, times and places, even in case that companies take great pains to fully integrate their marketing activities internally[10]. Enterprise can promote products through mixing four "P" strategies. A clear marketing strategy tool kit for enterprises selling digital products is provided through analyzing different categories of digital products with $4 \mathrm{P}$ as shown in Table 2 . We find that promotional tools of content-based digital products are more than others and combining trialability is different in three categories of digital products shown in Table 1. We argue that the less trialability a digital product is, the more promotional tools it needs.

\subsection{C Marketing Mix}

With market competition shifting from product-oriented into customer-oriented, some defects of $4 \mathrm{P}$ emerge. Under this condition, $4 \mathrm{C}$ marketing mix model is put forward by Lauterbom who suggest the marketing strategies that involved product, price, place and promotion are passe. Consumer wants and needs, cost to satisfy, convenience to buy and communication are the catechism for our times[7]. This model considers a marketing problem from the consumer perspective[10]. The content includes four points. First, what the customer want should be sold rather than what you can manufacture. Second, enterprise should take every efforts to decrease the cost of fulfilling the customer's demand. Third, enterprise should take every efforts to give convenience to customer for purchasing. Finally, communication with customer is more important than promotion. Analysis based on the $4 \mathrm{C}$ model of three categories digital products is shown in Table 3.

Now that we have a marketing strategy tool kit which are from customer's perspective for enterprises selling digital products. At the same time, we find that the less trialability a digital product is, the more communication tools it needs, which is the same finding as the $4 \mathrm{P}$ model. 
Table 2. 4P marketing strategy of different digital products

\begin{tabular}{|c|c|c|c|}
\hline & $\begin{array}{l}\text { Content-based digital products } \\
\text { (e-book) }\end{array}$ & $\begin{array}{l}\text { Utilities and tools (anti-virus } \\
\text { software) }\end{array}$ & $\begin{array}{l}\text { Online services (online } \\
\text { translation services) }\end{array}$ \\
\hline Product & $\begin{array}{l}\text { Products individual (the ssreader } \\
\text { divided e-book into single } \\
\text { chapter to sell) } \\
\text { Lock in (caj browser used by } \\
\text { China National Knowledge } \\
\text { Infrastructure) }\end{array}$ & $\begin{array}{l}\text { Quickly update version (kv3000 } \\
\text { anti-virus software put new } \\
\text { version each year) } \\
\text { Products individual (if you } \\
\text { purchase UFIDA U8 soft, you can } \\
\text { choose the module you need) } \\
\text { Binding (WPS Office) } \\
\text { Versioning (all version of WPS } \\
\text { Office) }\end{array}$ & $\begin{array}{l}\text { Lock in (QQ client) } \\
\text { Products individual (stock } \\
\text { trade online of West } \\
\text { Stock) }\end{array}$ \\
\hline Price & $\begin{array}{l}\text { Nonlinear pricing (ssreader's } \\
\text { reading card: RMB35/quarter, } \\
\text { RMB100/year, RMB180/two } \\
\text { years) } \\
\text { Individual price (products sold in } \\
\text { second hand market) } \\
\text { Value transfer (e-journal } \\
\text { provided in cfan web site, sell } \\
\text { quantity of journal is one of the } \\
\text { largest.) } \\
\text { Two-part price (fix monthly fee } \\
\text { of telephone and payment each } \\
\text { time) }\end{array}$ & $\begin{array}{l}\text { Group price (user of kv3000 net } \\
\text { version/RMB10/month) } \\
\text { Name your price(priceline.com.tw) } \\
\text { Two-part price(after purchase U8 } \\
\text { soft of UFIDA, you should pay } \\
\text { for using every year) } \\
\text { Value transfer(newhua.com is free, } \\
\text { revenue come from advertisement } \\
\text { for huge visiting stream) }\end{array}$ & $\begin{array}{l}\text { Individual price (lesson } \\
\text { online service of new } \\
\text { oriental in second hand } \\
\text { market) } \\
\text { Two-part price (there are } \\
\text { initial ISP service } \\
\text { payment then pay for } \\
\text { using each year) }\end{array}$ \\
\hline Place & Web store (dangdang.com) & $\begin{array}{l}\text { Web site constructed by } \\
\text { manufacturer (jiangmin.com) } \\
\text { web store (newhua.com) }\end{array}$ & $\begin{array}{l}\text { Web site constructed by } \\
\text { manufacturer } \\
\text { (russky.com) }\end{array}$ \\
\hline Promotion & $\begin{array}{l}\text { Recommendation(top } 10 \text { of } \\
\text { ssreader.com) } \\
\text { Personalization(When Mary } \\
\text { returns to the dangdang.com, it } \\
\text { responds "Hello Mary") } \\
\text { Comparison shopping } \\
\text { (pconline.com) } \\
\text { Customization (Yahoo China) } \\
\text { User comment list (ssreader.com) } \\
\text { Individual recommendation (“we } \\
\text { know you buy some E-business } \\
\text { books last time, there are some } \\
\text { related books for you”) } \\
\text { Rules-based system("the } \\
\text { exercises book is a good } \\
\text { complement to this book") } \\
\text { Ordering tools(shopping baskets) } \\
\text { Advertisement is involved in } \\
\text { product(book of ssreader.com) } \\
\text { Requirement register } \\
\text { (ssreader.com) } \\
\text { Digital watermark (photosl.net) }\end{array}$ & $\begin{array}{l}\text { Rules-based system (before } \\
\text { downloading update package, } \\
\text { please select version) } \\
\text { Ordering tools (shopping baskets) } \\
\text { Advertisement is involved in } \\
\text { product (flashget) } \\
\text { Trial (WPS Office provide limited } \\
\text { trial) } \\
\text { Authorization limitation (KV3000 } \\
\text { net version can check virus, but } \\
\text { can not update) } \\
\text { FAQs (jiangmin.com) }\end{array}$ & $\begin{array}{l}\text { Affiliates(russky.com) } \\
\text { FAQs (russky.com) } \\
\text { Instant Message (QQ) } \\
\text { BBS (bbs.russky.com) }\end{array}$ \\
\hline
\end{tabular}


Table 3. Marketing strategy of different categories digital products based on 4C

\begin{tabular}{|c|c|c|c|}
\hline & Content-based digital products (e-book) & $\begin{array}{l}\text { Utilities and tools } \\
\text { (anti-virus) }\end{array}$ & $\begin{array}{l}\text { Online services (online } \\
\text { translation services) }\end{array}$ \\
\hline $\begin{array}{l}\text { Consumer } \\
\text { wants and } \\
\text { needs }\end{array}$ & $\begin{array}{l}\text { Products individual (the ssreader divided } \\
\text { e-book into single chapter to sell) } \\
\text { Binding(browser is bind into e-book) } \\
\text { E-coupons(sozhao.com/tools/yhq/dangda } \\
\quad \text { ng.asp) } \\
\text { User comment list (ssreader.com) } \\
\text { Requirement register (ssreader.com) } \\
\text { Classified advertisement (8848.com) }\end{array}$ & $\begin{array}{l}\text { Quickly update version } \\
\text { (kv3000 anti-virus software } \\
\text { put new version each year) } \\
\text { Products individual (if you } \\
\text { purchase UFIDA U8 soft, } \\
\text { you can choose the module } \\
\text { you need) } \\
\text { Binding (WPS Office) } \\
\text { Versioning (all version of } \\
\text { WPS Office) } \\
\text { Advertisement of different } \\
\text { category (newhua.com) }\end{array}$ & $\begin{array}{l}\text { Products individual } \\
\text { (stock trade online of } \\
\text { West Stock) } \\
\text { Version (online } \\
\text { translation of } \\
\text { netat.net.cn can restrict } \\
\text { different subject) } \\
\text { Advertisement of } \\
\text { different } \\
\text { category(multi-languag } \\
\text { e translation of } \\
\text { netat.net.cn) }\end{array}$ \\
\hline Cost of satisfy & $\begin{array}{l}\text { Nonlinear pricing (ssreader's reading } \\
\text { card: RMB35/quarter, RMB100/year, } \\
\text { RMB180/2 years) } \\
\text { Individual price (products sold in second } \\
\text { hand market) } \\
\text { Two-part price (fix monthly fee of } \\
\text { telephone and pay each time) } \\
\text { Value transfer (e-journal provided in cfan } \\
\text { web site, sell quantity of journal is one } \\
\text { of the largest.) }\end{array}$ & $\begin{array}{l}\text { Group price(user of kv3000 } \\
\text { net version/RMB } \\
\text { 10/month) } \\
\text { Name you price } \\
\text { (priceline.com.tw) } \\
\text { Two-part price (after } \\
\text { purchase U8 soft of } \\
\text { UFIDA, you should pay for } \\
\text { using every year) } \\
\text { Value transfer (newhua.com } \\
\text { is free, revenue come from } \\
\text { advertisement for huge } \\
\text { visiting stream) }\end{array}$ & $\begin{array}{l}\text { Individual price (lesson } \\
\text { online service of new } \\
\text { oriental in second } \\
\text { hand market) } \\
\text { Two-part price (there } \\
\text { are initial ISP service } \\
\text { payment then pay for } \\
\text { using each year) }\end{array}$ \\
\hline $\begin{array}{l}\text { Convenience to } \\
\text { buy }\end{array}$ & $\begin{array}{l}\text { Web store (dangdang.com) } \\
\text { Ordering tools (shopping baskets) } \\
\text { Security policy (see the privacy and } \\
\text { security notice on ssreader.com) } \\
\text { Comparison shopping (pconline.com) } \\
\text { Virtual reality (e360.cn) }\end{array}$ & $\begin{array}{l}\text { Web site constructed by } \\
\text { manufacturer } \\
\text { (jiangmin.com) } \\
\text { Ordering tools (shopping } \\
\text { baskets) } \\
\text { Security policy (see the } \\
\text { privacy and security notice } \\
\text { on ssreader.com) } \\
\text { Trial (WPS Office provide } \\
\text { limited trial) }\end{array}$ & $\begin{array}{l}\text { Web site constructed by } \\
\text { manufacturer } \\
\text { (russky.com) } \\
\text { Security policy (see the } \\
\text { privacy and security } \\
\text { notice on } \\
\text { ssreader.com) }\end{array}$ \\
\hline Communication & $\begin{array}{l}\text { Recommendation (the suggestion on } \\
\text { ssreader.com) } \\
\text { Personalization (When Mary returns to } \\
\text { the dangdang.com, it responds "Hello } \\
\text { Mary") } \\
\text { Customization (Yahoo China) } \\
\text { Individual recommendation ("we know } \\
\text { you buy some E-business books last } \\
\text { time, there are some related books for } \\
\text { you”) } \\
\text { Rules-based system (“the exercises book } \\
\text { is a good complement to this book") } \\
\text { Trial (free } 17 \text { pages in ssreader.com ) } \\
\text { Online auction (ebay.com.cn) } \\
\text { FAQs (ssreader.com) } \\
\text { Digital community (Sun digital } \\
\text { community) }\end{array}$ & $\begin{array}{l}\text { Rules-based system (before } \\
\text { downloading update } \\
\text { package, please select } \\
\text { version) } \\
\text { Advertisement is involved in } \\
\text { product (flashget) } \\
\text { Trial (WPS Office provide } \\
\text { limited trial) } \\
\text { Authorization limitation } \\
\text { (KV net version can check } \\
\text { virus, but can not update) } \\
\text { FAQs (jiangmin.com) } \\
\text { Auction (ebay.com.cn) }\end{array}$ & $\begin{array}{l}\text { Affiliates (russky.com) } \\
\text { FAQs (russky.com) } \\
\text { Instant message(QQ) } \\
\text { BBS (bbs.russky.com) } \\
\text { Digital community (Sun } \\
\text { digital community) }\end{array}$ \\
\hline
\end{tabular}




\subsection{S Marketing Mix}

The 4S model (web-marketing model, WMM) was put forward by Constantinides [10]. It describes web marketing strategy with four elements begin with "S" including scope, site, synergy and system. The goal of this model is to design and develop marketing mix for BtoC online projects through controlling four "S" elements. In $4 \mathrm{~S}$ model, the scope element is of primarily strategic character and outlines the decisions to be made on four areas: (a) the strategic and operational objectives of the online venture; (b) the market definition including measuring the market potential and the identification/classification of the potential competitors, visitors and customers of the site; (c) the degree of readiness of the organization for E-Commerce; (d) the strategic role of E-Commerce for the organization. The web site is therefore the functional platform of communication, interaction and transaction with the web customer. The prime mission of the web Site is to attract traffic, establish contact with the online target markets and brand the online organization. The synergy factor embraces a wide range of issues divided into three categories: the front office, the back office and the third parties. The front office refers to conventional corporate communication and distribution strategies; The back office synergy includes three issues: (a) the integration of E-Commerce physical support into existing organizational processes; (b) the legacy integration; (c) integration of the online operation into the company's value system. The success in virtual marketplace often requires co-operation with Internet partners outside the organization and its value system. Finally, the system factor identifies the technological issues as well as the site servicing issues to be addressed by the E-Commerce management.

The $4 \mathrm{~S}$ model brings out how to prepare a web marketing strategy on two issues. First, on strategic layout, the main strategic problem is planned which is insurance of creating successful web marketing strategy. The $4 \mathrm{~S}$ model emphasizes that web marketing strategy should consistent with enterprise strategy. Web marketing strategies should integrate with other operation strategy and take full advantage of competition advantage. Second, on operation layout, a methodology for making web marketing strategy is provided.

\section{Discussion}

There is an interesting finding in Table 2 and Table 3 that the lower trialability of digital products is, the more promotional tools it needs. A probable explanation is that digital products are a kind of experience products, consumers can understand the product after purchasing it [3]. So the best promotion tool is trial, through trial, consumer will persuade himself to purchase. Refering Table 1 , utilities and tools is the best in trialability while content-based product is the worst in trialability. So promotion of content-based product should be achieved by multi-marketing tools except trial. The other two categories of products can be promoted by trial. That is to say, three categories of products have notable difference in promotion tools. We can sum up this point as: 
Trial is the best promotion tool for digital products. With high trialability, the digital products needs less promotion tools. At the same time, with low trialability, the digital products needs more promotion tools.

\begin{tabular}{|c|c|c|c|}
\hline & $\begin{array}{c}\text { Content-based digital products } \\
\text { (e-book) }\end{array}$ & Utilities and tools(anti-virus) & $\begin{array}{l}\text { Online services(online } \\
\text { translation services) }\end{array}$ \\
\hline $\begin{array}{l}\text { Scope (strategy } \\
\text { and objective) }\end{array}$ & $\begin{array}{l}\text { Market segmentation (demographic } \\
\text { variables, geographic variables, } \\
\text { psychographic variables and } \\
\text { behavioral variables) } \\
\text { Potential customers (profiles, } \\
\text { motivation, behavior and needs) } \\
\text { Internal analysis(internal resources, } \\
\text { value process, and the web } \\
\text { sustaining technology) } \\
\text { Strategic role of the web activities } \\
\text { (information platform, educational, } \\
\text { promotional and transactional) }\end{array}$ & Same as left & Same as left \\
\hline $\begin{array}{l}\text { Web site (online } \\
\text { experience) }\end{array}$ & $\begin{array}{l}\text { Link exchange (Coolgo e-book, } \\
\text { ssreader) } \\
\text { Advertisements } \\
\text { Factors of web site (domain, } \\
\text { content, design, layout, } \\
\text { atmosphere etc) } \\
\end{array}$ & $\begin{array}{l}\text { Optimize of speed of web site } \\
\text { Factors of web site (domain, } \\
\text { content, design, layout, } \\
\text { atmosphere etc) }\end{array}$ & $\begin{array}{l}\text { Optimize of speed of web site } \\
\text { Factors of web site (domain, } \\
\text { content, design, layout, } \\
\text { atmosphere etc) }\end{array}$ \\
\hline $\begin{array}{c}\text { Synergy } \\
\text { (integration) }\end{array}$ & $\begin{array}{l}\text { Web store (dangdang.com) } \\
\text { The back office (physical book } \\
\text { store) }\end{array}$ & $\begin{array}{l}\text { Web site construct by } \\
\text { manufacturer (jiangmin.com) } \\
\text { The front office (updating } \\
\text { product installed in client) }\end{array}$ & $\begin{array}{l}\text { Web site construct by } \\
\text { manufacturer (russky.net/trans/) } \\
\text { Third parties (outsource of } \\
\text { logistic) }\end{array}$ \\
\hline $\begin{array}{c}\text { System } \\
\text { (technology } \\
\text { requirement) }\end{array}$ & $\begin{array}{l}\text { Technology requirement of web } \\
\text { site (stabilization, security, } \\
\text { software, hardware, protocol, } \\
\text { system service etc) } \\
\text { Preliminary payment system } \\
\text { (ssreader) }\end{array}$ & $\begin{array}{l}\text { Technology requirement of } \\
\text { web site (stabilization, } \\
\text { security, software, hardware, } \\
\text { protocol, system service etc) } \\
\text { Instant payment system } \\
\text { (kv3000) } \\
\text { Post-payment system (net } \\
\text { version RMB10/month) } \\
\end{array}$ & $\begin{array}{l}\text { Technology requirement of web } \\
\text { site (stabilization, security, } \\
\text { software, hardware, protocol, } \\
\text { system service etc) } \\
\text { Instant payment system(in web } \\
\text { site (russky.net/trans/) payment } \\
\text { can be finished by SMS(short } \\
\text { message system) and network) }\end{array}$ \\
\hline
\end{tabular}

Delivery mode in Table 1 can partly explain different place strategies in Table 2. Value of content-based products can transfer through download mode, if adopting a web store, the distributions cost is low. Value transfer of online services need to interact with the customer, web site construction by manufacturer is only a feasible way. For frequent updates (e.g., update of the package) of utilities and tools, enterprises selling utilities and tools often constructed web site by itself. Web stores is a feasible tool on condition that updates are not required.

Comparing $4 \mathrm{~S}$ model with the $4 \mathrm{P}$ and $4 \mathrm{C}$ models, we find strategic elements involved in $4 \mathrm{~S}$ model that distinguish from others. It is combined of strategy marketing with tactics marketing. For products needing manufactures construction web site by itself as a distribution channel, it is necessary to select a target market from the market segmentation according to position. Those are important to design web site. The web site of online service is often constructed by manufacturers and there are some strategic elements, including position and target market selection, affect web site's business status except promotion instrument 
including advertisement etc. That is to say, the $4 \mathrm{~S}$ model is a feasible marketing strategic tool kit for enterprises selling online service. There are parts of enterprises of selling utilities and tools constructing a web site by themselves, the $4 \mathrm{~S}$ model is suitable for them. Enterprises selling content-based products seldom construct web site by itself, the suitability of $4 \mathrm{~S}$ model is low. The $4 \mathrm{C}$ model considers a marketing problem from the consumer perspective. Customer's demand can be easy fulfill while the difference ability of products is high. Therefore, $4 \mathrm{C}$ model is suitable for products with high difference ability. Content-based products have the highest difference ability, which can reconstruct with different segments to distinguish from others and with no additional cost. Online services have a medium difference ability which decided by its high trialability, but some cost accompany trialing. Utilities and tools have low difference ability which can not be reconstructed randomly. In summary, the $4 \mathrm{C}$ model has high suitability of content-based products and medium suitability of online service and low suitability of utilities and tools. The $4 \mathrm{P}$ model has more controllable ability of four elements than others, so the $4 \mathrm{P}$ model is suitable for utilities and tools well. The $4 \mathrm{~S}$ model is suitable for utilities and tools on condition that manufacturer constructing web site himself. Under this condition, it is best to combine the $4 \mathrm{P}$ model and the $4 \mathrm{~S}$ model. The other two products have medium suitability for the 4P model. Analyzing of the above can summarized into three findings:

For content-based products, the $4 \mathrm{P}$ model is much more suitable than the $4 \mathrm{C}$ model, while the $4 C$ model is more suitable than the $4 S$ model.

For utilities and tools, the $4 P$ and the $4 S$ models are more suitable than the $4 C$ model.

For online service, the $4 S$ model is more suitable than the $4 P$ and $4 C$ models.

\section{Conclusion}

There are three contributions of this study. First,with unique characteristics in economic and physical property, the classic marketing models including $4 \mathrm{P}, 4 \mathrm{C}$ and $4 \mathrm{~S}$ have different conditions in applying to the selling of digital product. Second, for each catagroities of digital products, the priority of suitability of established marketing mix models is provided. Third, there is an interesting finding that the less trialability a digital product is, the more promotional tools it needs.

\section{References}

1. Guo, J.Z., Sun, C.Z.: Global Glectronic Markets and Global Traditional Markets. Electronic Markets, 14(1)(2004):4-25

2. Kalyanam, K., Mclntyre, S.: The E-marketing Mix: A Contribution of the E-tailing Wars. Journal of the Academy of Marketing Science, 30(4)(2002):487-499

3. Koiso-Kanttila: Digital Content Marketing: A Literature Synthesis. Journal of Marketing Management, 20(2004):45-65 
4. Rayport, J.F., Sviokla, J.J.: Managing in the Marketspace. Harvard Business Review, 72(6)(1994):141-150

5. Mahajan, V., Venkatesh, R.: Marketing Modeling for E-Business. International Journal of Research in Marketing, 17(2000):215-225

6. Hoffman, D.L., Novak, T.P.: A New Marketing Paradigm for Electronic Commerce. The Information Society: An International Journal, 13(1997):43-54

7. Lauterborn, B.: New Marketing Litany: Four P's Passe: C-Words Take Over. Advertising Age, 61(41)(1990):26

8. Mahadevan, B.: Business Models for Internet-based E-Commerce: An Anatomy. California Management Review, 42(2000):4-20

9. Kierzkowski, A. et al: Marketing to the Digital Consumer. The McKinsey Quarterly, 3(1996):5-21

10. Constantinides, E.: The $4 \mathrm{~S}$ Web-Marketing Mix Model. Electronic Commerce Research and Applications, 1(2002):57-76

11. Angehrn, A.: Designing Mature Internet Business Strategies: the ICDT Model. European Management Journal, 15(4)(1997):361-369

12. Patty, T.: Mastering the Five P's of Marketing. 1997, www.chiatday.com/raw materials / insights /5ps/5p mkt.html

13. Koivumäki, T.: Customer Satisfaction and Purchasing Behavior in a Web-based Shopping Environment. Electronic Markets, 11(3)(2001):186-192

14. Werbach, K.: The Emerging Model for Business in the Internet Era. Harvard Business Review, May-June(2000):84-94

15. Shapiro, C., Varian, H.: Versioning: The Smart Way to Sell Information. Harvard Business Review, November-December(1998):105-114

16. Zhang, J., Jiang J.Q.: Sharing Information Goods and its Way of Organizing: an Economic Analysis. China Economic Quarterly, 1(4)(2001):937-952

17. Shapiro, C., Varian, H., Translated by Zhang, F.: Information Rules: A Strategic Guide to the Network Economy. China RenMin University Press, 2000.6

18. Wang K.L.: The Economic Characteristics, Classification and Pricing Strategy of Digital Products. China Soft Science Magazine, 6(2002):58-62

19. Hui, K.L., Chau, P.Y.K.: Classifying Digital Products. Communication of the ACM, 45(6)(2002):72-80

20. Hoffman, D.L., Novak, T.P.: How to Acquire Customers on the Web. Harvard Business Review, May-June(2000):179-186 